\title{
$\mathrm{PV}$ 모듈의 셀 면적 비에 따른 공기식 PVT 컬렉터의 열 및 전기성능 비교·분석 연구
}

\author{
이길선 ${ }^{1} \cdot$ 유지숙 ${ }^{2} \cdot$ 김진희 ${ }^{3} \cdot$ 김준태 ${ }^{4+}$ \\ ${ }^{1}$ 공주대학교 에너지시스템공학과, 석사과정 \\ 2공주대학교 에너지시스템공학과, 박사과정 \\ ${ }^{3}$ 공주대학교 그린에너지기술연구소, 연구교수 \\ 공주대학교 건축학부 건축공학전공/에너지시스템공학과, 교수
}

\section{Analysis of Thermal and Electrical Performance for Air-Type PVT Collectors According to PV Module Cell Ratios}

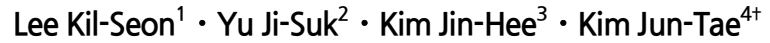 \\ ${ }^{1}$ M.S. Student, Department of Energy System Engineering, Kongju National University \\ ${ }^{2}$ Ph.D. Student, Department of Energy System Engineering, Kongju National University \\ ${ }^{3}$ Research Professor, Green Energy Technology Research Center, Kongju National University \\ ${ }^{4}$ Professor, Department of Architectural Engineering, Kongju National University \\ ${ }^{\dagger}$ Corresponding author: jtkim@kongju.ac.kr
}

\section{OPEN ACCESS}

Journal of the Korean Solar Energy Society Vol.41, No.1, pp.47-58, February 2021 https://doi.org/10.7836/kses.2021.41.1.047

\section{pISSN : 1598-6411}

elSSN : 2508-3562

Received: 5 October 2020

Revised: 18 January 2021

Accepted: 18 January 2021

Copyright (C) Korean Solar Energy Society

This is an Open-Access article distributed under the terms of the Creative Commons Attribution NonCommercial License which permits unrestricted non-commercial use, distribution, and reproduction in any medium, provided the original work is properly cited.

\begin{abstract}
The air-type photovoltaic / thermal (PVT) collector is a solar collector that acquires heat generated from the back of the PV module through the circulation of air behind the collector, while the PV module uses solar energy to produce electrical energy. In this process, electricity is produced through PV modules, and heat energy is produced through a heat collection process using air as the heat medium. According to the PV cell ratio, air-type PVT collectors differ in the collector's thermal and electrical performance. The higher the PV cell ratio of the PV module, the more is the ratio of PV cells per unit area, thereby increasing the total electricity generation of the collector. However, when the PV cell ratio is lowered, the glass to back sheet (GtoB) transparent type PV module increases the area of the light-permeating part. Therefore, the air heat behind the PV module increases, thereby improving the thermal performance of the collector. In this study, outdoor testing was conducted in accordance with the test conditions of ISO9806:2017 to investigate the thermal and electrical performance of an air-type PVT collector. A comparative experiment was carried out for: (i) Case 1 (PV cell ratio of 0.9) with a perforated baffle, and (ii) Case 2 (PV cell ratio of 0.67) with a lower PV cell ratio to improve thermal performance. Based on the inlet flow rate and the PV cell ratio of air-type PVT collectors, the thermal and electrical efficiencies were analyzed and compared.
\end{abstract}

Keywords: 공기식 태양광 열 복합 컬렉터(Air-type PVT collector), 셀 면적 비(PV cell ratio), 열효율(Thermal efficiency), 전기효율(Electrical efficiency) 


\section{기호설명}

$$
\begin{array}{ll}
A_{p v t} & : \text { 공기식 } \mathrm{PVT} \text { 컬렉터 면적 }\left(\mathrm{m}^{2}\right) \\
\mathrm{G} & : \text { 일사량 }\left(\mathrm{W} / \mathrm{m}^{2}\right) \\
\dot{M}_{i} & : \text { 입구유량 }(\mathrm{kg} / \mathrm{h}) \\
\dot{M}_{o} & : \text { 출구유량 }(\mathrm{kg} / \mathrm{h}) \\
C_{f a m b} & : \text { 외기 비열 }(\mathrm{J} / \mathrm{kg} \cdot \mathrm{K}) \\
C_{f i} & : \text { 입구공기 비열 }(\mathrm{J} / \mathrm{kg} \cdot \mathrm{K}) \\
C_{f o} & : \text { 출구공기 비열 }(\mathrm{J} / \mathrm{kg} \cdot \mathrm{K}) \\
T_{a m b} & : \text { 외기온도 }\left({ }^{\circ} \mathrm{C}\right) \\
T_{i} & : \text { 입구공기 온도 }\left({ }^{\circ} \mathrm{C}\right) \\
T_{o} & : \text { 출구공기 온도 }\left({ }^{\circ} \mathrm{C}\right) \\
\dot{Q} & : \text { 획득열량 }(\mathrm{W}) \\
I_{m} & : \text { 최대전류 }(\mathrm{A}) \\
V_{m} & : \text { 최대전압(V) } \\
\eta_{t h} & : \text { 열효율 } \\
\eta_{e l} & : \text { 전기효율 }
\end{array}
$$

\section{1.서론}

건물의 에너지 수요 증가는 환경오염과 지구온난화를 유발시키는 원인이 되며 이러한 상황 속에서 재생에너 지 활용 기술은 높아지는 에너지 수요에 대한 대안이다. 다양한 재생에너지 활용 기술 중에서 태양광 · 열 복합 시스템(Photovoltaic/Thermal System ; 이하PVT 시스템)은 PV 모듈이 태양에너지를 이용하여 전기에너지를 생산하는 과정에서 모듈 후면으로 발생되는 열을 이용하는 기술이다. PVT 시스템은 PV 후면으로 방출되는 열 을 이용하므로 PV 모듈의 온도상승으로 인한 발전량 감소 문제를 해결하고 전기와 열에너지를 하나의 시스템 내에서 동시에 생산할 수 있다는 장점이 있다.

PVT 시스템은 열매체의 종류에 따라 공기식과 액체식, 공기과 액체를 모두 사용하는 복합식으로 나뉜다. 이 중 공기식 PVT 시스템은 액체식에 비해 열효율은 상대적으로 낮지만 열매체의 순환을 위한 팬을 제외하고 별 도의 주변 설비 없이 가열된 공기를 난방에 이용하는 것이 가능하다. 또한 액체식과 달리 공기를 열매체로 이용 하기 때문에 동절기 시스템의 동결 우려나 액체의 누수로 인한 컬렉터나 시스템의 손상에 대한 우려가 없다1).

공기식 PVT 컬렉터의 효율은 전면 PV 모듈의 종류, 열매체의 유량, 내부 유로 설계, 셀 면적 비(컬렉터의 PV 모듈 면적에서 PV 셀이 차지하는 비율) 등 다양한 변수들에 의해 영향을 받는다. 국내· 외에서는 이러한 변수들 
에 변화를 주어 공기식 PVT 컬렉터의 열 및 전기성능을 향상시키는 연구들이 수행되고 있다.

국내에서 Kim et al. ${ }^{2}$ 은 공기식 PVT 컬렉터 내부에 새로운 형태의 베플을 적용하여 컬렉터의 성능을 측정하 는 실험을 진행하였다. 컬렉터 내부의 베플은 절곡된 둥근 형태의 흡열 동판으로 공기의 유로를 길어지게 하고 이를 통해 컬렉터의 열 및 전기성능을 향상시키는 새로운 유형의 공기식 PVT 컬렉터를 개발하였다. 해당 실험 은 ISO 9806 표준성능시험에 근거하여 옥외에서 진행되었고 입구유량 $100 \mathrm{~m}^{3} / \mathrm{h}$ 조건에서 컬렉터의 열 및 전기 효율은 각각 $37.99 \%, 16.21 \%$ 로 나타났다. Kim et al. ${ }^{3)}$ 은 공기식 PVT 컬렉터의 공급유량조건을 변화시켜 컬렉 터의 열 및 전기효율과 표면온도의 변화를 측정하였다. 실험결과 최소유량 $\left(100 \mathrm{~m}^{3} / \mathrm{h}\right)$ 에서 최대유량 $\left(200 \mathrm{~m}^{3} / \mathrm{h}\right)$ 으로 공급유량이 상승할 경우 열효율은 25,72\%에서 $32.56 \%$ 로 증가하였다. 유량이 증가함에 따라 컬렉터의 표 면온도는 약 $11^{\circ} \mathrm{C}$ 가 감소하였으며 표면온도의 감소로 인해 전기효율은 $14.93 \%$ 에서 $15.54 \%$ 까지 증가하는 것 으로 확인되었다.

국외의 경우 Yan et al. ${ }^{4}$ 은 공기식 PVT 컬렉터의 후면에 얇은 알루미늄 육각기둥들이 일정한 패턴 형태를 이 룬 허니컴 구조의 판을 적용하여 새로운 형태의 공기식 PVT 컬렉터를 개발하였다. 해당 실험은 PV 모듈이 컬렉 터 전면을 차지하는 비율에 따라 변화하는 컬렉터의 열효율을 확인하였다. 실험결과 $600 \mathrm{~W} / \mathrm{m}^{2}$ 의 빛을 조사했 을 때, PV 모듈이 컬렉터 전면을 차지하는 최적이 비율은 45\%로 나타났으며 최대 순간 열효율은 $64 \%$ 로 나타났 다. Ooshaksaraei et al. ${ }^{5}$ 은 공기식 PVT 컬렉터의 PV 셀 면적 비를 변수로 하여 수학적 모델과 실험을 통해 총 에너지효율을 비교하였다. 그 결과 PV 셀이 점유하고 있는 면적이 50\%에서 $70 \%$ 로 상승할수록 컬렉터의 총 에 너지 효율은 51\%에서 59\%로 상승하였다. 그리고 Wu et al. ${ }^{6}$ 은 공기식 PVT 컬렉터 전면 PV 셀의 점유비율을 $73 \%$ 에서 $50 \%$ 로 낮추어 컬렉터의 성능을 평가하는 실험을 진행하였다. 전면 PV 셀의 점유비율이 $73 \%$ 일 때, 컬렉터의 열효율은 $27 \%$ 로 나타났으며 점유비율이 $50 \%$ 일 때, $36 \%$ 까지 상승하는 것으로 나타났다. 결과적으로 컬렉터 전면의 PV 셀 면적 비가 낮아지면 셀 사이의 간격이 넓어지기 때문에 PV 후면 공기층까지 도달하는 일 사가 늘어나 컬렉터의 열효율이 높아지는 것으로 분석되었다. Vats et al. ${ }^{7)}$ 은 건물 지붕에 통합된 공기식 반투 명 태양광/열 복합 모듈에서 전체 컬렉터 면적 대비 전체 PV 셀 면적의 비율(이하; Packing factor)가 PV 모듈 에 미치는 영향을 분석하였다. Packing factor가 0.83에서 0.42 로 감소하면 PV 모듈의 온도가 $10^{\circ} \mathrm{C}$ 감소하여 $0.2 \sim 0.6 \%$ 의 전기효율증가를 보였다. HIT(이종접합) PV 모듈에서 Packing factor가 0.62일 때, 0.83 보다 연 간 열에너지 생산량은 $83 \mathrm{kWh}$, 엑서지는 $32 \mathrm{kWh}$ 더 높은 것으로 분석되었다. Meraj et al. ${ }^{8}$ 은 PV 모듈에서 셀 면적 비가 모듈 성능에 미치는 영향을 수치해석(MATLAB)을 이용하여 분석하였다. PV 모듈의 셀 면적 비가 0.89 일 때, 전력생산량이 약 $200 \mathrm{Wp}$ 로 가장 높았지만 셀 온도 또한 $65^{\circ} \mathrm{C}$ 로 가장 높았으며, 셀 면적비가 0.25 인 경우 전력생산량은 $50 \mathrm{Wp}$ 로 가장 낮았지만 셀 온도는 $40^{\circ} \mathrm{C}$ 로 가장 낮은 것으로 나타났다. 결과적으로 동일조 건의 컬렉터에서 셀 면적비가 높을수록 전력생산량 측면에서는 유리하지만 PV 셀 온도는 가장 높아지는 것으 로 분석되었다.

위와 같이 공기식 PVT 컬렉터의 다양한 요소들에 변화를 주어 컬렉터의 성능이 어떻게 변화하는지 측정하는 
실험연구들이 다수 이뤄지고 있다. 공기식 PVT 컬렉터는 베플, 방열핀, PV셀 면적비 등 설계요소에 따라 성능 에 영향을 받는 것으로 밝혀졌다.

본 논문에서는 컬렉터의 열 및 전기성능 향상을 위해 PV 셀 면적 비를 낮추어 열 성능을 개선한 공기식 PVT 컬렉터를 설계 제작하여 PV 셀면적비에 따른 성능을 비교 실험하였다. 두 가지 형태의 공기식 PVT 컬렉터의 성 능평가를 위해 태양열 집열기 표준성능시험(ISO 9806)에 근거하여 옥외실험을 진행하였으며 동시에 같은 실 험 조건 하에서 열 및 전기성능을 측정하고 PV 셀 면적 비가 성능에 미치는 영향을 분석하였다.

\section{2. 공기식 PVT 컬렉터 디자인 및 실험방법}

\section{1 공기식 PVT 컬렉터 디자인}

본 연구에서는 공기식 PVT 컬렉터의 열 및 전기성능을 향상시키기 위하여 새로운 형태의 컬렉터를 설계하였다 (Fig. 1). 해당 컬렉터는 전면 G/B타입의 PV 모듈, 타공된 베플패널 단열재, 백 플레이트 순서로 구성되어있다. G/B 타입의 PV 모듈은 Glass to Back-sheet 타입으로, 유리, PV 셀, 후면 투명 백시트로 구성되어 있다. 컬렉터 전 체 사이즈는 $1013 \times 1672 \times 32 \mathrm{~mm}$ 이며, 타공된 베플패널이 전면 PV 모듈과 후면 백 플레이트 사이에 위치해 있 다. 베플 패널은 열 흡수판의 역할까지 담당하며 타공된 알루미늄 판으로 제작되었다. 베플패널은 CFD 분석을 통 해 베플의 각도, 간격, 높이, 상부 길이, 타공 시 개구율 등 성능에 영향을 주는 요소들을 분석하여 디자인하였다).
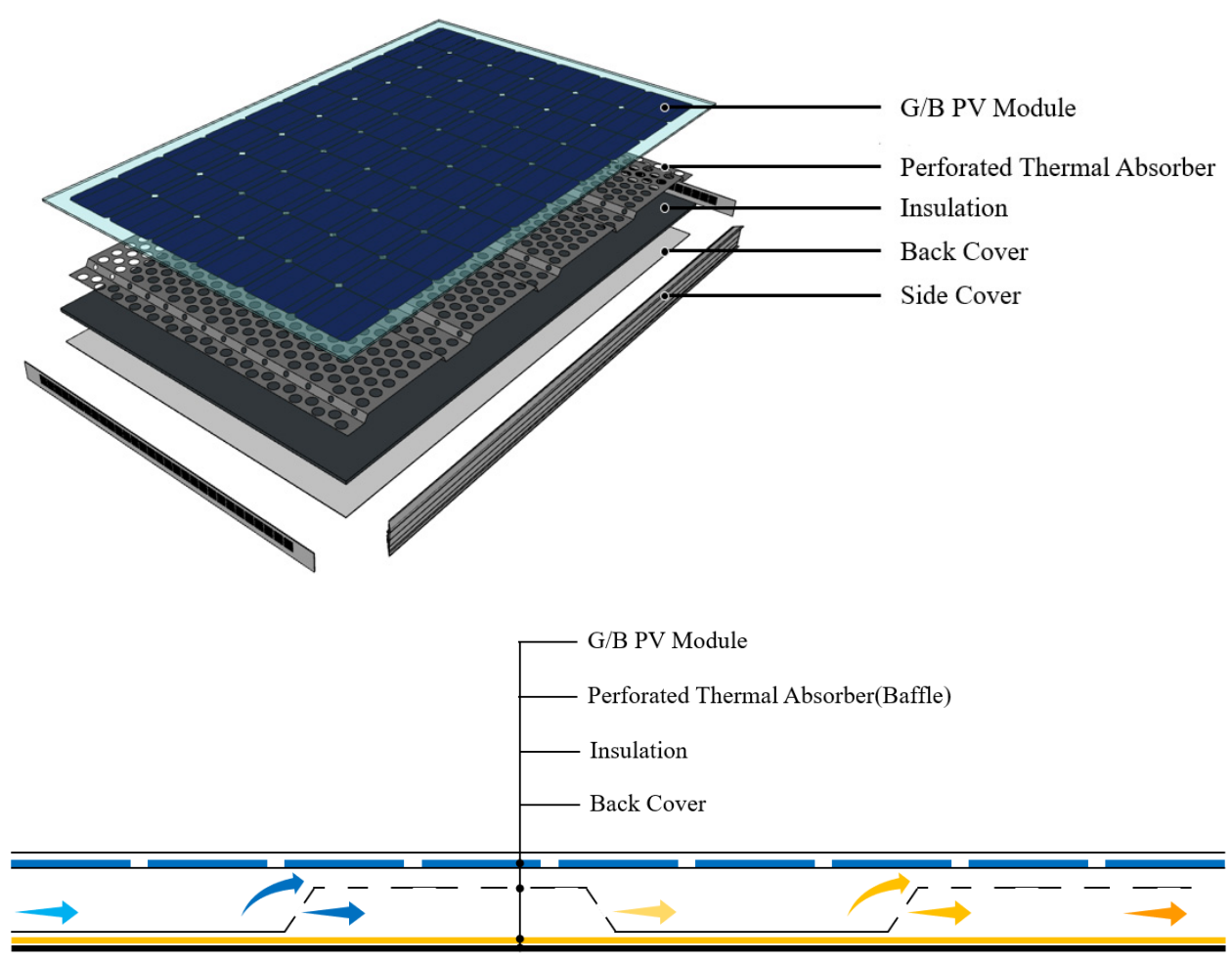

Fig. 1 Schematic Design of Air-type PVT Collector 
실험에 사용된 컬렉터의 전면 PV 모듈 면적은 $1.63 \mathrm{~m}^{2}$ 이며 후면 구조나 프레임 등 동일한 규격을 가진다. 실 험에 사용된 컬렉터에 적용된 PV 모듈의 상세 사양 및 개념도는 Table 1에 나와 있으며 PV 셀 면적 비는 식(1) 과 같이 산정된다. Fig. 2는 Case별 PV 모듈의 형태 및 셀 사이 간격을 나타낸 그림이다. Case 1은 60개의 셀이 전면에 부착되어있고 PV 셀 사이의 간격은 $2 \mathrm{~mm}$, 컬렉터의 PV 셀 면적은 $1.46 \mathrm{~m}^{2}$, 셀 면적 비는 0.9 이다. Case 2의 경우, 45개의 셀이 부착되어있으며 셀 사이의 상하간격과 좌우간격은 각각 $21 \mathrm{~mm}$ 와 $40 \mathrm{~mm}$, 컬렉터의 PV 셀 면적은 $1.10 \mathrm{~m}^{2}$ 로 셀 면적 비는 0.67 이다.

$$
\text { PVCell Ratio }=\frac{P V \text { cell area }\left(m^{2}\right)}{P V \bmod \text { ule area }\left(m^{2}\right)}
$$

Table 1 PV module specification (Case 1 \& Case 2)

\begin{tabular}{ccc}
\hline Parameters & Case 1 & Case 2 \\
\hline Cell type & Mono-crystalline Silicon $(60$ cell) & Mono-crystalline Silicon (45 cell) \\
Module size & $1638 \times 996 \times 6 \mathrm{~mm}$ & $1638 \times 996 \times 6 \mathrm{~mm}$ \\
\hline Space between cells & $2 \mathrm{~mm}$ & Vertical : $21 \mathrm{~mm}$ \\
Cell area & $1.46 \mathrm{~m}^{2}$ & Horizontal : $40 \mathrm{~mm}$ \\
Module efficiency & $17.51 \%$ & $1.10 \mathrm{~m}^{2}$ \\
Maximum power $\left(P_{\max }\right)$ & $285 \mathrm{~W}$ & $12.94 \%$ \\
Maximum voltage $\left(V_{m p}\right)$ & $34.1 \mathrm{~V}$ & $211 \mathrm{~W}$ \\
Maximum current $\left(I_{m p}\right)$ & $8.4 \mathrm{~A}$ & $24.7 \mathrm{~V}$ \\
Open voltage $\left(V_{o c}\right)$ & $41.1 \mathrm{~V}$ & $8.5 \mathrm{~A}$ \\
Short current $\left(I_{s c}\right)$ & $8.8 \mathrm{~A}$ & $30.8 \mathrm{~V}$ \\
Fill factor & $78.51 \%$ & $9.1 \mathrm{~A}$ \\
\hline
\end{tabular}

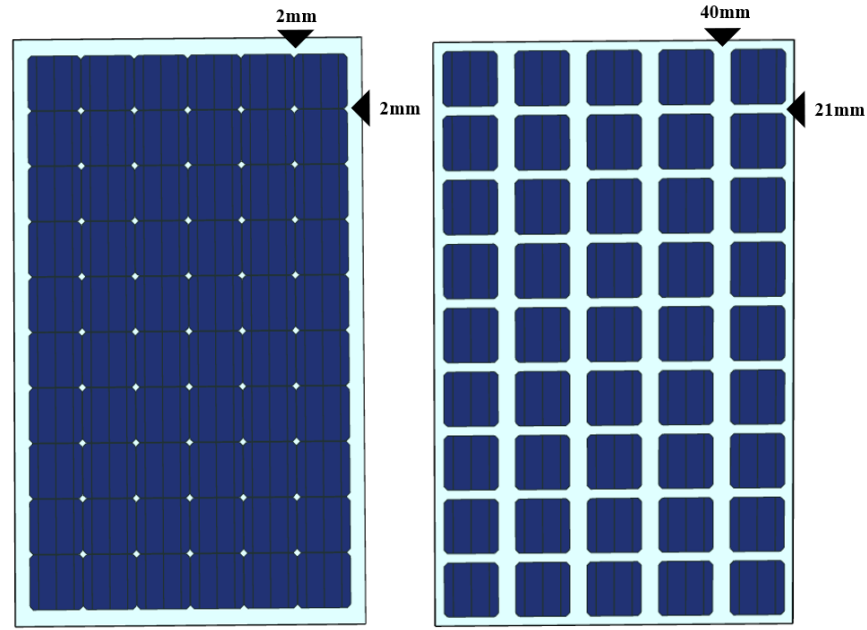

Fig. 2 Outdoor Experiments of Air-type PVT Collector (Case 1 \& Case 2) 


\section{2 실험방법}

Case 1과 Case 2 두 가지 공기식 PVT 컬렉터는 ISO 9806:2017 ${ }^{10)}$ 태양열 집열기 실험 표준에 기초하여 옥외 성능평가가 진행되었다. 공기식 PVT 컬렉터는 수평 $\left(0^{\circ} \sim 160^{\circ}\right)$, 수직 $\left(15^{\circ} \sim 90^{\circ}\right)$ 으로 조절이 가능한 2축 솔라 트래커에 설치되었으며 태양의 이동방향에 따라 트래커를 수동으로 조절하여 컬렉터가 태양과 법선 면을 유지 할 수 있다(Fig. 3). 두 가지 컬렉터의 열 및 전기성능을 평가하기 위하여 컬렉터의 입·출구 온도 및 습도, 유량, PV 모듈 후면 온도, 일사량, 외기 온도 및 습도, 풍향풍속, 전력량이 측정되었다. 옥외실험을 통한 데이터 실측 기간은 2020년 4월 5월 중 Case 2 컬렉터 부착 후(4월 27일 5월 1일) Case 1 컬렉터(5월 6일 11일)와 교 체를 통해 실험을 진행하였다.
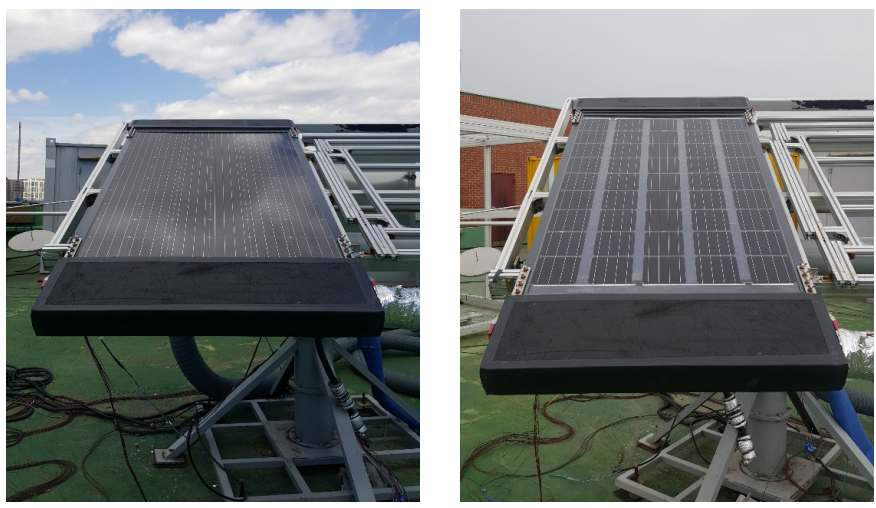

Fig. 3 Outdoor Experiments of Air-type PVT Collector (Case 1 \& Case 2)

ISO 9806:2017 $7^{10}$ 의 실험 방법에 따라 공기식 PVT 컬렉터 평면의 일사 강도가 $700 \mathrm{~W} / \mathrm{m}^{2}$ 이상에서 컬렉터 입 · 출구 온도 및 습도, 유량, 풍속이 정상상태일 경우에 10초 간격으로 10 분 동안 데이터를 수집하였다. 컬렉터의 후 면 유량 조건은 일정한 간격으로 $\left(100,150,200 \mathrm{~m}^{3} / \mathrm{h}\right)$ 유량 조건을 변경하여 측정하였다. 정상상태는 수집되는 실 험 데이터가 Table 2에 나와 있는 해당 데이터의 정상상태 범위를 유지하는 경우를 정상상태 조건으로 보았다.

Table 2 Permitted deviation of measured parameters during a measurement period (ISO 9806)

\begin{tabular}{cc}
\hline Parameters & $\begin{array}{c}\text { Permitted deviation from the mean value } \\
\text { - Air heating collector - }\end{array}$ \\
\hline $\begin{array}{c}\text { Hemispherical solar irradiance } \\
\text { Thermal irradiance }\end{array}$ & $\pm 50 \mathrm{~W} / \mathrm{m}^{2}$ \\
Ambient air temperature & $\pm 20 \mathrm{~W} / \mathrm{m}^{2}$ \\
Fluid mass flowrate & $\pm 2 \%$ \\
Fluid temperature at the collector inlet & $\pm 1.5 \mathrm{~K}$ \\
Fluid temperature at the collector outlet & $\pm 1.5 \mathrm{~K}$ \\
Surrounding air speed & $\pm 1.0 \mathrm{~m} / \mathrm{s} \mathrm{deviation} \mathrm{from} \mathrm{set} \mathrm{value}$
\end{tabular}




\section{3. 실험결과 및 분석}

공기식 PVT 컬렉터의 열 성능을 평가하는 열효율은 다음 식(2) ${ }^{10)}$ 과 같이 산정된다.

$$
\begin{aligned}
& \eta_{t h}=\frac{\dot{Q}}{A_{p v t} G} \\
& \dot{Q}=\left(\dot{m}_{o} C_{f o} T_{o}\right)-\left(\dot{m}_{i} C_{f i} T_{i}\right)-\left[\left(\dot{m}_{o}-\dot{m}_{i}\right) C_{f a m b} T_{a m b}\right]
\end{aligned}
$$

또한 공기식 PVT 컬렉터의 전기성능을 평가하는 전기효율은 다음 식(4) ${ }^{11)}$ 와 같이 산정된다.

$$
\eta_{e l}=\frac{I_{m} V_{m}}{A_{p v t} G}
$$

Case 1과 Case 2 공기식 PVT 컬렉터의 성능비교 실험은 컬렉터 입구 유량을 변수로 설정하였고 실험기간 내 평균 외기온도는 $25.13^{\circ} \mathrm{C}$, 평균 일사량은 $885.28 \mathrm{~W} / \mathrm{m}^{2}$ 으로 나타났다.

\section{1열성능}

본 연구에서는 공기식 PVT 컬렉터의 입구유량과 일사량에 따른 Case 1과 Case 2의 열효율과 각각의 조건에서 입구유량에 따른 열성능을 비교하였다. Figs. 4 와 5 는 일사량과 입구유량 변화에 따른 Case 1 과 Case 2 의 열효율 을 분석한 그래프이며 결과 값은 Table 3에 정리하였다. Case 1의 경우 일사량이 $820 ~ 920 \mathrm{~W} / \mathrm{m}^{2}$ 로 증가함에 따라 $100 \mathrm{~m}^{3} / \mathrm{h}$ 의 경우 열효율은 $24 \sim 27 \%$ 로 측정되었다. $150 \mathrm{~m}^{3} / \mathrm{h}$ 는 $28 \sim 34 \%, 200 \mathrm{~m}^{3} / \mathrm{h}$ 의 경우 $36 \% ~ 39 \%$ 로 나타났다. Case 2의 경우 일사량이 $810 \sim 930 \mathrm{~W} / \mathrm{m}^{2}$ 으로 증가함에 따라 $100 \mathrm{~m}^{3} / \mathrm{h}$ 의 경우 열효율은 29

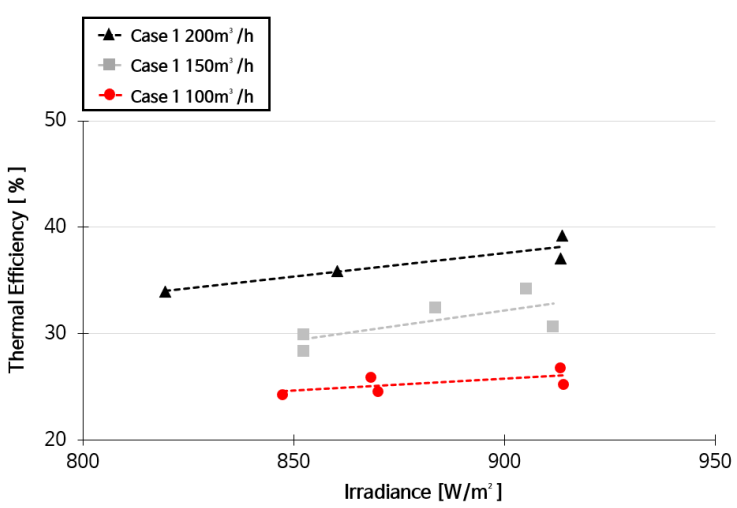

Fig. 4 Thermal Efficiency of Air-type PVT Collector (Case 1)

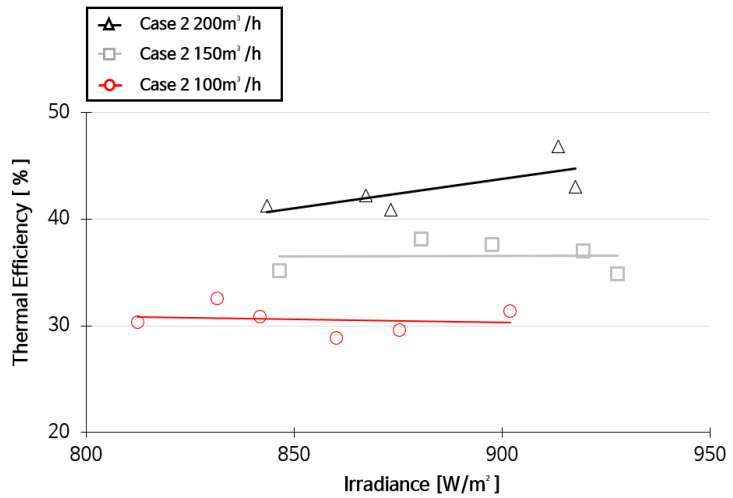

Fig. 5 Thermal Efficiency of Air-type PVT Collector (Case 2) 
$33 \%$ 로 측정되었다. $150 \mathrm{~m}^{3} / \mathrm{h}$ 는 $35 \sim 38 \%, 200 \mathrm{~m}^{3} / \mathrm{h}$ 의 경우 $41 \sim 47 \%$ 로 나타났다. 두 그래프 모두 일사량이 증가함에 따라 컬렉터의 열효율이 증가하는 추세를 보였고 입구유량이 $100 \sim 200 \mathrm{~m}^{3} / \mathrm{h}$ 으로 증가함에 따라 열 효율이 높아지는 것으로 분석되었으며 전반적으로 Case 1보다 Case 2의 열효율이 높은 것으로 나타났다.

Table 3 Thermal Efficiency of Case 1 \& Case 2

\begin{tabular}{cccc}
\hline & $100 \mathrm{~m}^{3} / \mathrm{h}$ & $150 \mathrm{~m}^{3} / \mathrm{h}$ & $200 \mathrm{~m}^{3} / \mathrm{h}$ \\
\hline Case 1 & $24 \sim 27 \%$ & $28 \sim 34 \%$ & $36 \sim 39 \%$ \\
Case 2 & $29 \sim 33 \%$ & $35 \sim 38 \%$ & $41 \sim 47 \%$ \\
\hline
\end{tabular}

Fig. 6은 외기온도 $25 \sim 27^{\circ} \mathrm{C}$, 컬렉터 입구유량 $150 \mathrm{~m}^{3} / \mathrm{h}$, 일사량 $890 \mathrm{~W} / \mathrm{m}^{2}$ 조건에서 Case 1 과 Case 2의 PV 모듈 후면의 온도를 비교한 그래프이다. Case 1 의 PV 모듈 후면온도는 평균 $50.4^{\circ} \mathrm{C}$, 컬렉터 입 · 출구 온도차 $9.5^{\circ} \mathrm{C}$, Case $2 \mathrm{PV}$ 모듈 후면온도는 평균 $43.8^{\circ} \mathrm{C}$, 입 · 출구 온도 차는 $11.4^{\circ} \mathrm{C}$ 로 측정되었다. Case 2 가 Case 1 에 비해 컬렉터의 열효율이 더 높지만 Case 1에 비해 PV 모듈 후면의 온도가 $6.6^{\circ} \mathrm{C}$ 낮고 컬렉터 입 · 출구 공기의 온도 차이가 $1.9^{\circ} \mathrm{C}$ 큰 이유는 PV 셀 면적 비의 차이로 컬렉터 전면의 투광부 면적이 Case 1에 비해 Case 2가 $25 \%$ 높아 일사가 전면 유리를 통해 컬렉터의 공기채널로 직접 도달하는 양이 많아지기 때문이다.

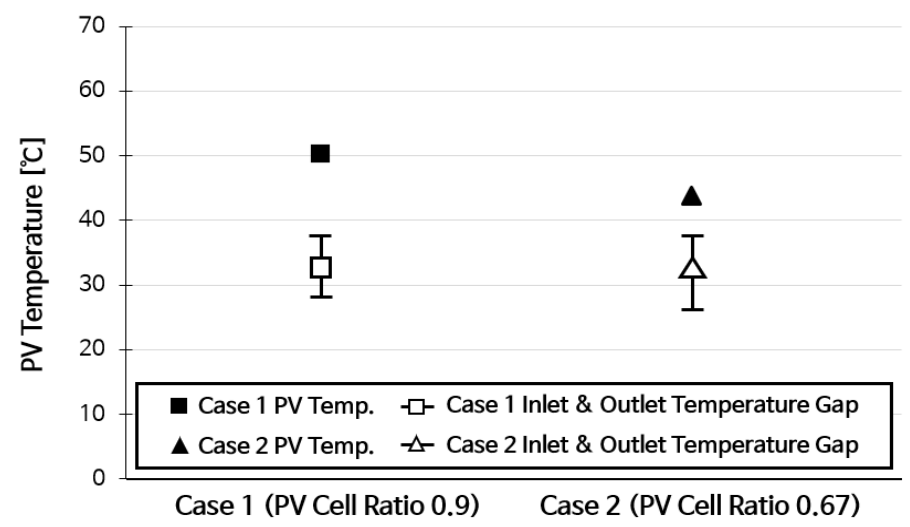

Fig. 6 PV Temperature comparison of Air-type PVT Collectors (Case 1 \& Case 2)

\section{2 전기성능}

Fig. 7은 일사량에 따른 Case 1과 Case 2 컬렉터의 PV 셀 효율 및 PV 모듈 후면의 온도를 분석한 그래프이다. 컬렉터 입구유량을 $150 \mathrm{~m}^{3} / \mathrm{h}$ 로 설정하였을 때, Case 1의 경우 일사량이 $850 \sim 911 \mathrm{~W} / \mathrm{m}^{2}$ 로 증가함에 따라 PV 모듈 후면의 온도는 $47 \sim 54^{\circ} \mathrm{C}$ 로 증가하였으며 PV 모듈의 셀 효율이 $18.21 \sim 17.80 \%$ 로 감소하는 것으로 나타 났다. Case 2의 경우 일사량이 $846 \sim 927 \mathrm{~W} / \mathrm{m}^{2}$ 로 증가함에 따라 PV 모듈 후면의 온도는 $41 \sim 45^{\circ} \mathrm{C}$ 로 증가하 여 PV 모듈의 셀 효율이 18.64 17.94\%로 감소하는 것으로 나타났다. PV 셀 면적 비가 상대적으로 높은 Case 
1 의 경우 Case 2 에 비해 PV 모듈 후면의 온도가 $6.4^{\circ} \mathrm{C}$ 높았으며 그에 따라 셀 효율도 평균 $18 \%$ 로 Case 2 의 $18.3 \%$ 보다 낮은 것으로 분석되었다.

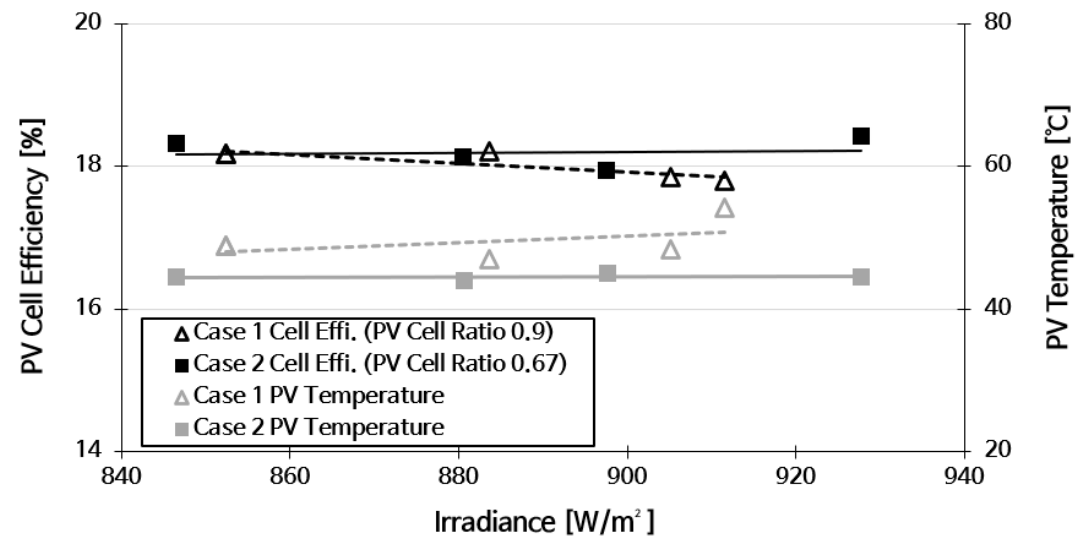

Fig. 7 PV Cell Efficiency of Air-type PVT Collector (Case 1 \& Case 2)

Fig. 8은 전체 유량조건에서 PV 셀 면적 비에 따른 Case 1과 Case 2 컬렉터의 평균 데이터를 이용하여 PV 최 대 출력 및 셀 효율을 나타낸 그래프이며 수집된 최대출력 데이터와 셀 효율 데이터는 Table 4에 정리하였다. Case 1의 경우 컬렉터 후면 유량조건이 상승할수록 평균 최대 출력은 227 234 W이고 Case 2 의 경우 172 $180 \mathrm{~W}$ 로 나타났으며 평균 셀 효율은 Case 1이 18.07 18.33\%, Case 2는 18.14 18.50\%로 측정되었다. 컬렉 터의 최대 출력에서 차이를 보이는 이유는 PV 셀 면적 비가 상대적으로 높을수록 컬렉터의 단위 면적 당 PV 셀 의 숫자가 많아지므로 더 많은 전기에너지를 생산하기 때문으로 분석되었다. 전기성능 측면에서 Case 1 은 최대 출력이 $285 \mathrm{~W}$ 로 용량 대비 81.1\%인 $231 \mathrm{~W}$ 로 측정되었고 Case 2는 최대 출력이 $211 \mathrm{~W}$ 로 용량대비 83.8\%인 $177 \mathrm{~W}$ 로 측정되어 Case 1에 비해 Case 2가 더 유리한 것으로 나타났다. 이렇게 컬렉터의 용량 대비 최대 출력 에서 차이가 발생하는 이유는 컬렉터의 PV 모듈 후면의 온도 차이 때문으로 분석되었는데 Case 1 의 경우 $48.7^{\circ} \mathrm{C}$, Case 2 의 경우 $44.2^{\circ} \mathrm{C}$ 로 Case 1 컬렉터의 평균 PV 모듈 후면 온도가 더 높았다. 또한 두 컬렉터의 PV 셀은 같은 사양의 셀이지만 PV 모듈 후면의 온도 차이로 인해 Case 1 컬렉터의 셀 효율은 평균 18.18\%, Case 2 컬렉터가 $18.30 \%$ 로 Case 1 컬렉터의 평균 셀 효율이 $2 \%$ 더 낮았다. 결과적으로 전면 PV 모듈을 제외한 같은 형태의 컬 렉터에서 PV 셀 면적 비가 상대적으로 높으면 발전 용량 측면에서는 유리하지만 PV 모듈 후면의 온도상승으로 인한 손실 때문에 발전 용량 대비 최대 출력 및 셀 효율 측면에서는 불리한 것으로 분석되었다.

Table 4 PV Power \&PV Cell Efficiency of Case 1 \& Case 2

\begin{tabular}{cccc}
\hline & $100 \mathrm{~m}^{3} / \mathrm{h}$ & $150 \mathrm{~m}^{3} / \mathrm{h}$ & $200 \mathrm{~m}^{3} / \mathrm{h}$ \\
\hline Case 1 & $228 \mathrm{~W} / 18.07 \%$ & $232 \mathrm{~W} / 18.13 \%$ & $234 \mathrm{~W} / 18.33 \%$ \\
Case 2 & $172 \mathrm{~W} / 18.14 \%$ & $179 \mathrm{~W} / 18.23 \%$ & $180 \mathrm{~W} / 18.50 \%$ \\
\hline
\end{tabular}



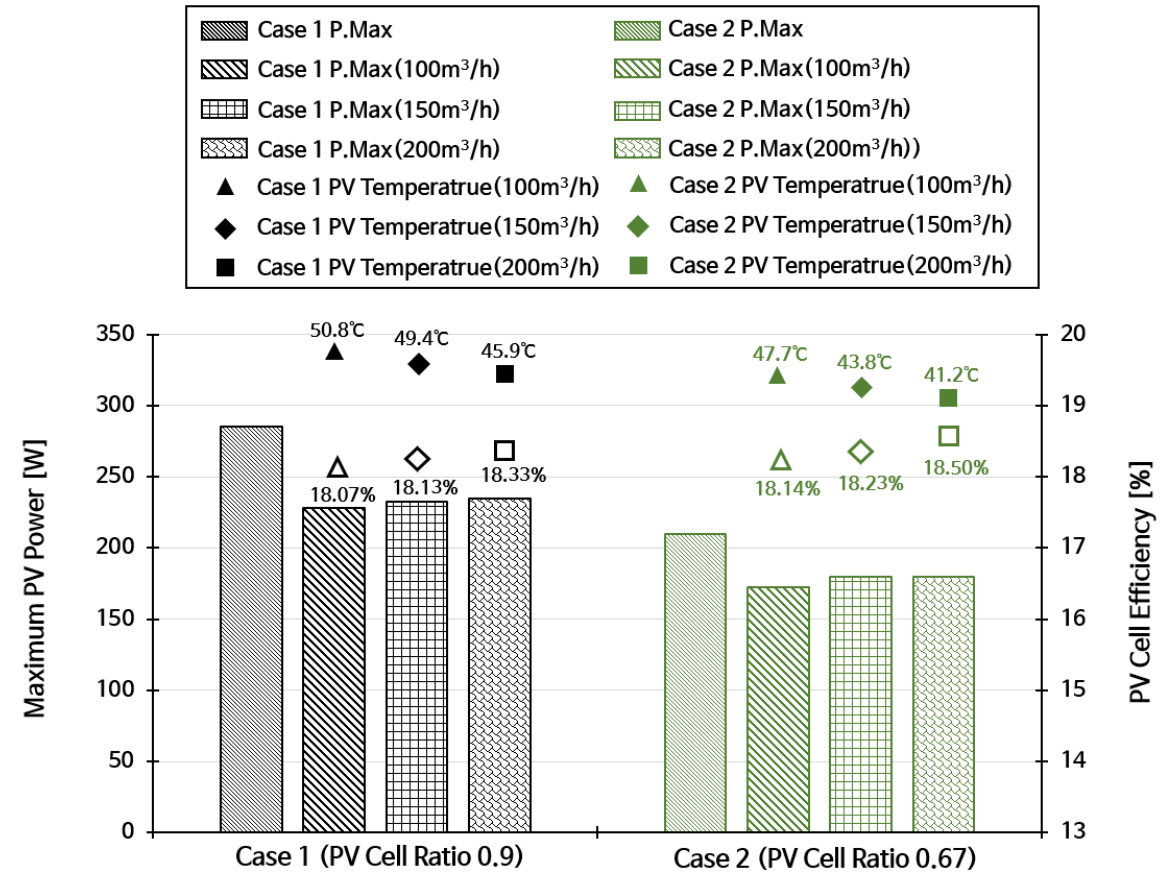

Fig. 8 Maximum PV Power \& PV Cell Efficiency related to PV Cell Ratio

\section{4. 결론}

본 연구에서는 옥외실험을 통해 공기식 PVT 컬렉터 전면 PV 모듈의 PV 셀 면적 비에 따른 컬렉터의 열 및 전기성능을 확인하고 비교 및 분석하였다. Case 1과 Case 2 공기식 PVT 컬렉터의 성능시험은 입구유량 조건 $\left(100 \sim 200 \mathrm{~m}^{3} / \mathrm{h}\right)$ 에 변화를 주어 진행하였으며 각각의 열 및 전기성능에 관한 분석결과는 아래와 같다.

(1) 공기식 PVT 컬렉터 입구로 유입되는 공기의 유량을 증가시킬 때, Case 1의 경우 24 39\%, Case 2의 경 우 29 47\%로 컬렉터의 열효율이 높아지는 것을 확인하였다. 이는 컬렉터의 입구유량이 증가함에 따라 후면 공기채널 내에서 열매체가 획득하는 열량이 증가하기 때문인 것으로 분석되었다.

(2) 공기식 PVT 컬렉터 전면 PV 모듈의 PV 셀 면적 비가 감소함에 따라 PV 셀 사이의 간격이 넓어지게 되고 이로 인해 전면 PV 모듈의 면적에서 투광부가 차지하는 비율이 증가하여 컬렉터 내부 공기채널 까지 도 달하는 일사가 늘어났기 때문에 Case 1에 비해 Case 2 컬렉터의 열효율이 $14 \%$ 높은 것으로 나타났다.

(3) 컬렉터 입구유량이 $150 \mathrm{~m}^{3} / \mathrm{h}$ 조건에서 Case 1은 Case 2보다 단위면적 당 PV 셀의 숫자가 많기 때문에 최 대 출력은 더 높지만 셀 효율은 낮은 것으로 확인되었다. PV 모듈 후면 온도가 Case 2에 비해 Case 1 컬렉 터가 더 높아 PV 모듈의 온도 상승에 의한 손실이 발생하는 것으로 분석되었다.

(4) PV 모듈의 최대 출력 측면에서 Case 1이 Case 2에 비해 $23 \%$ 높았지만 셀 효율 측면에서는 약 $2 \%$ 낮은 것 으로 나타났으며 열 성능은 Case 1에 비해 Case 2 컬렉터가 약 $7 \%$ 높은 성능을 나타내었다. 이를 통해 종 
합적인 열 및 전기성능 측면에서 Case 2의 컬렉터가 Case 1 컬렉터보다 우수한 것으로 분석되었다.

결과적으로 공기식 PVT 컬렉터는 컬렉터 입구로 유입되는 공기의 유량이 증가할 때, 컬렉터의 열 성능이 향 상되는 것으로 나타났다. 또한 동일 유량 조건에서 PV 셀 면적 비가 낮은 컬렉터는 열 성능 측면에서 상대적으 로 유리한 것으로 나타났으며 PV 셀 면적 비가 높은 컬렉터는 셀 면적 비가 낮은 컬렉터에 비해 발전량 측면에 서 유리한 것으로 나타났다. 그러나 PV 셀 면적 비가 높은 컬렉터는 PV 모듈의 온도상승으로 인해 PV셀 효율 측면에서는 PV 셀 면적 비가 낮은 컬렉터에 비해 불리한 것으로 확인되었다. 그러므로 공기식 PVT 컬렉터는 컬 렉터 설계 단계에서 전면 PV 모듈의 셀 면적 비를 고려하여 발전성능과 열성능 중 어떠한 측면에 중점을 두어야 할지 고려하여 설계하여야 한다.

\section{후 기}

본 연구는 산업통상자원부(MOTIE)와 한국에너지기술평가원(KETEP)의 지원을 받아 수행한 연구 과제입 니다(No. 20188550000480, No. 20173010013420).

\section{REFERENCES}

1. Kim, J. H. and Kim, J. T., A Literature Review on Hybrid PV/Thermal Air Collector in terms of its Design and Performance, Journal of the Korean Solar Energy Society, Vol. 34, pp. 30-41, 2014.

2. Kim, S. M., Kim, J. H., and Kim, J. T., An Experimental Study on Thermal and Electrical Performance of an Air-type PVT Collector, Journal of the Korean Solar Energy Society, Vol. 39, No. 2, pp. 23-32, 2019.

3. Kim, Y. J., Lee, K. S., Kang, E. C., and Lee, E. J., The Impact of a PVT Air Flow Rate and Panel Temperature on Thermal and Power Efficiency, The Korean Society of Mechanical Engineers, pp. 85-87, 2017.

4. Yan, Z., Meng, T., Jing, C. J., Hu, J. A., and Qian, S. R., Experimental and Numerical Investigation on Thermal Performance of PV-driven Aluminium Honeycomb Solar Air Collector, Solar Energy, Vol. 204, pp. 294-306, 2020.

5. Ooshaksaraei, P., Sopian, K., Zaidi, S. H., and Zulkifli, R., Performance of Four Air-based Photovoltaic Thermal Collectors Configurations with Bifacial Solar Cells, Renewable Energy, Vol. 102, pp. 279-293, 2017.

6. Wu, J. S., Lin, D. Y., Li, Y. G., Hsu, H. P., Kao, M. C., and Chen, H. Z., Optical Characterization and Photovoltaic Performance Evaluation of GaAs p-i-n Solar Cells with Various Metal Grid Spacings, Crystals, Vol. 9, No. 3, 170, 2019.

7. Vats, K., Tomer, V., and Tiwari, G. N., Effect of Packing Factor on the Performance of a Building Integrated Semitransparent Photovoltaic Thermal (BISPVT) System with Air Duct, Energy And Buildings, Vol. 53, pp. 159-165, 2012.

8. Meraj, M., Khan, M. E., Tiwari, G. N., and Istiyaque, M., Packing Factor Effects on the Performance of Photovoltaics Module for a Given Module Area, 3rd International Innovative Applications of Computational Intelligence on Power, Energy and Controls with Their Impact on Humanity (CIPECH), pp. 30-33, 2018.

9. Yu, J. S., Kim, J. H., and Kim, J. T., A Study for Improving Thermal Performance According to Variables of 
Perforated Baffle in Air-type PVT Collector, Journal of the Korean Solar Energy Society, Vol. 39, No. 6, pp. 83-91, 2019.

10. ISO 9806:2017, Solar energy - Solar thermal collectors - Test methods, International Organization for Standard, 2017.

11. Euh, S. H., Lee, J. B., Choi, Y. S., and Kim, D. H., The Performance and Efficiency Analysis of a PVT System Compared with a PV Module and a Solar Collector, Journal of the Korean Solar Energy Society, Vol. 32, pp.1-10, 2012. 